\title{
Paradieuches dissimilis (Distant, 1883) - new genus and new species of seed bug (Heteroptera: Lygaeidae) in the fauna of Russia from the South of the Far East
}

\section{Paradieuches dissimilis (Distant, 1883) - новый род и новый вид полужесткокрылых (Heteroptera: Lygaeidae) для фауны России с юга Аальнего Востока}

\author{
Nikolai N. Vinokurov \\ H.H. Винокуров
} Institute for Biological Problems of Cryolithozone SB RAS, Pr. Lenina 41, Yakutsk 677000, Russia. E-mail: n_vinok@mail.ru
Институт биологических проблем криолитозоны СО РАН, пр. Ленина 41, Якутск 677980, Россия.

KEY WORDS: Heteroptera, Lygaeidae, Drymini, fauna, Russian Far East.

КЛЮЧЕВЫЕ СЛОВА: Heteroptera, Lygaeidae, Drymini, полужесткокрылые, фауна, Дальний Восток России.

ABSTRACT. Paradieuches dissimilis (Distant, 1883 ) is recorded for the first time for the fauna of Russia from Polonsky Is. of the Small Kuril Ridge. This East Asian representative of the new for Russian fauna genus Paradieuches Distant, 1883 is widespread in Japan, on the Korean peninsula, south-west and southeast of China.

РЕЗЮМЕ. С острова Полонского Малой Курильской гряды впервые приводится клоп семейства Lygaeidae (Drymini) — Paradieuches dissimilis (Distant, 1883). Этот восточноазиатский представитель также нового для фауны России рода Paradieuches Distant, 1883 распространён в Японии, на Корейском полуострове, юго-западе и юго-востоке Китая.

\section{Introduction}

Research carried out for many years on Kunashir Island, the southernmost island of the Kuril archipelago, has revealed a species rich and peculiar fauna of true bugs (Heteroptera), close in composition to the fauna of the more southern Hokkaido Island comprising 244 species of 28 families [Kerzhner et al., 2004; Vinokurov, Kanyukova, 2016; Vinokurov, 2017]. At the same time, examination of new material sent to me from the Kurilsky Nature Reserve shows that the faunal list is by no means complete but is still being supplemented with genera and species of bugs new to the faunas of the island, the Russian Far East, and Russia. In 2017, a representative of the South Asian genus Paradieuches
Distant, 1883 from the family Lygaeidae was collected for the first time on Kunashir Island by Yu.N. Sundukov and L.A. Sundukova. Information about this species is given herein.

The examined specimen is deposited in the collection of Heteroptera of the Zoological Institute, Russian Academy of Sciences (St. Petersburg; ZIN).

\section{Paradieuches dissimilis (Distant, 1883)}

Figs 1-8.

Dieuches dissimilis Distant, 1883: 483; Lethierry, G. Severin, 1894: 219; Oshanin, 1912: 38; Ishihara T., 1953: 112; Miyamoto, 1957: 73.

Paradieuches dissimilis: Scudder, 1962: 770.

MATERIAL. 1 o - Russia: Kuril Is., Small Kuril Ridge, western part of Polonsky Is., 1-8.07.2017, Yu. Sundukov, L. Sundukova, (ZIN); $1 \mathrm{O}^{7}$ — Japan: Hokkaido, Tomakomai Experimental Forestry Station, Iburi District, 18-22.07.1997, N. Vinokurov, (IBPC).

MORPHOLOGY. Female. Body rather narrow, elongated, 3.1 times as long as wide. Body length $5.5 \mathrm{~mm}$, body width behind middle of hemelytra $1.75 \mathrm{~mm}$ (Fig. 1). Head, pronotum and scutellum black, dull, hemelytra shiny.

Head extending forward, shorter than wide, with protruding clypeus, very finely punctated. White adpressed pubescence sparse on frons and denser on head sides, between antennae, on clypeus and on underside of head. Ocelli widely separated, located behind eyes. Bucculae low, ending at level of antennal tubercles. Labium reaching middle coxae; Labial segment I reaching prothorax, brown; other segments yellowbrown. Antennae with short pale setae, segments I and II dirty yellow, mesial surface of segment I with prominent spinules basally and apically, segment III black with brown base, segment IV black. Length of antennal segments: I - 0.7, II -1.1 , III -1.0 , IV $-1.1 \mathrm{~mm}$.

How to cite this article: Vinokurov N.N. 2019. Paradieuches dissimilis (Distant, 1883) — new genus and new species of seed bug (Heteroptera: Lygaeidae) in the fauna of Russia from the South of the Far East // Russian Entomol. J. Vol.28. No.1. P.1 -4. doi: 10.15298/rusentj.28.1.01 


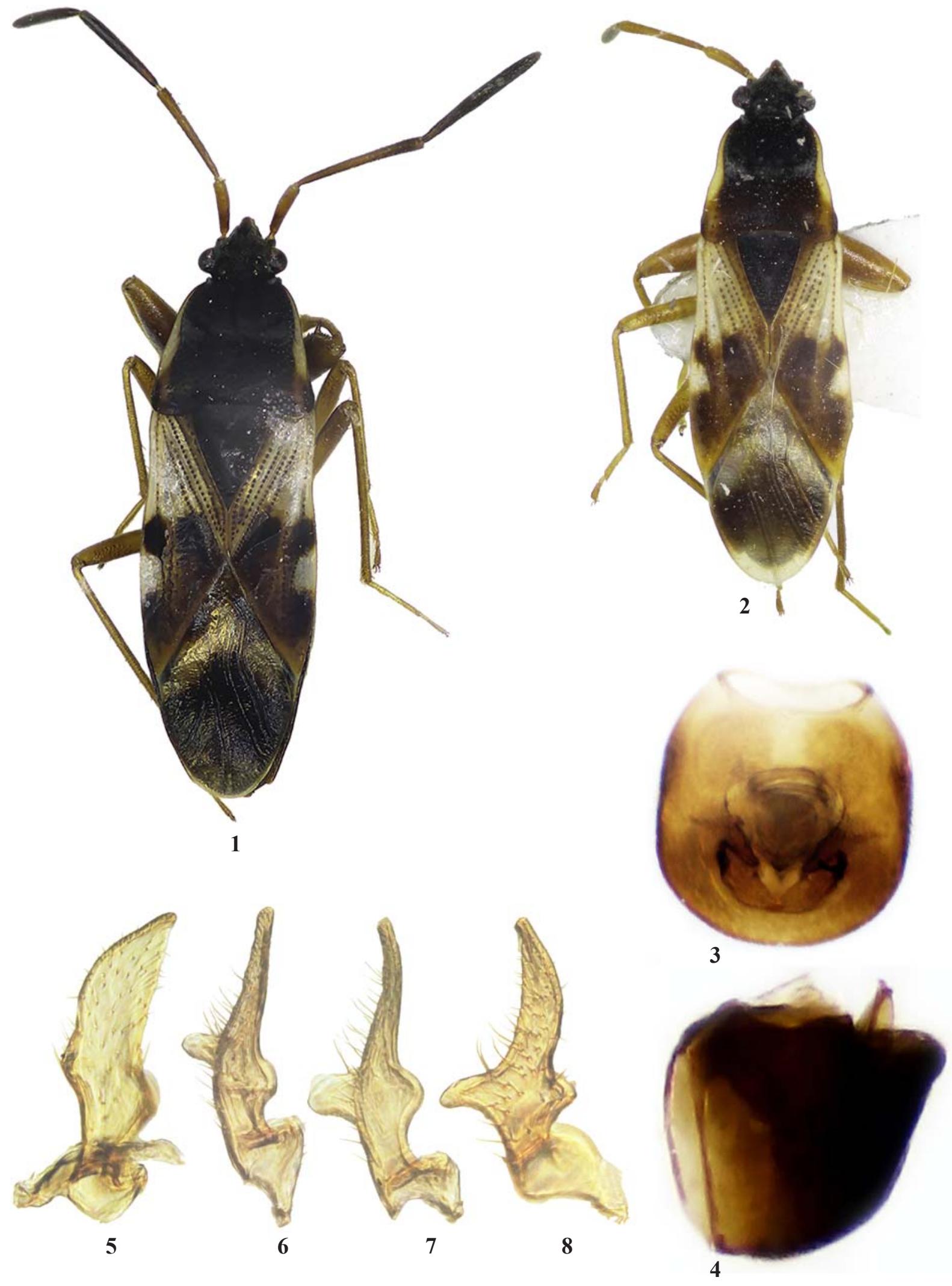

Figs 1-8. Paradieuches dissimilis: 1-2 - habitus; $3-4-$ genital capsule; $5-8-$ paramere in various positions; $1-9$, Polonsky Is.; 2-8 - $0^{2}$, Hokkaido Is.; $1-3-$ dorsal view; 4 - lateral view.

Pис. 1-8. Paradieuches dissimilis: 1-2 - внешний вид; 3-4 - генитальная капсула; 5-8 - парамер в разных положениях; 1 ㅇ, о. Полонского; 2 - ○', о. Хоккайдо; 1-3 - сверху; 4 - сбоку. 
Pronotum trapeziform, width at base, with lateral margins straight, smoothly narrowing toward apex, posterior margin deeply emarginate. Pronotal disc black, shallowly depressed behind middle, distinctly punctated, with punctation sparse on elevated callus areas, with very short white hairs located in punctures. Lateral margins of pronotum laminate, yellow along their entire length, wide in posterior half, narrowing anteriorly, with thin black edging.

Thoracic venter dimly lustrous with silvery tinge, deep coarse punctation and very short white setae; scent gland area dull. Fore femora thickened, brown, with one large denticle and two rows of small denticles at middle. Middle and hind femora, all tibiae and tarsi dirty yellow. Tibiae with sparse pale spinules and short setae. Hind tarsomere I twice as long as tarsomeres II and III combined.

Scutellum sparsely punctated. Hemelytra reaching tip of abdomen, weakly concave before middle, weakly dilated in posterior half. Clavus with three rows of brown-black punctures, whitish yellow generally, yellow along inner margin, brownish apically. Corium whitish in basal half, with inter- rupted black band at middle, apical part brown to dark brown; with two rows of coarse dark punctures along inner margin and with fine, often colourless punctures along veins, distal half with sparse black punctation. Membrane translucent, with 3 yellowish spots basally, yellow apically, with large bluish black spot at middle.

Abdomen black, with rather dense short adpressed golden hairs.

REMARKS. For comparison, I examined a conspecific male from Hokkaido Island (Fig. 2). Body length $5.1 \mathrm{~mm}$, maximal width $1.2 \mathrm{~mm}$, length to width ratio 3.1. Pronotum with concave lateral margins. Coloration paler than in female from the Polonsky Island: legs yellow, pattern on posterior half of corium dark brown, membrane white basally and apically, brownish black at middle.

The genus Paradieuches belongs to the tribe Drymini Stål, 1872 and the subfamily Rhyparochrominae. The genus is known from South-East Asia [Slater, 1964; Slater, O'Donnel, 1995] and includes only two species: P. lewisi Distant, 1883, endemic to southern islands of the Japanese

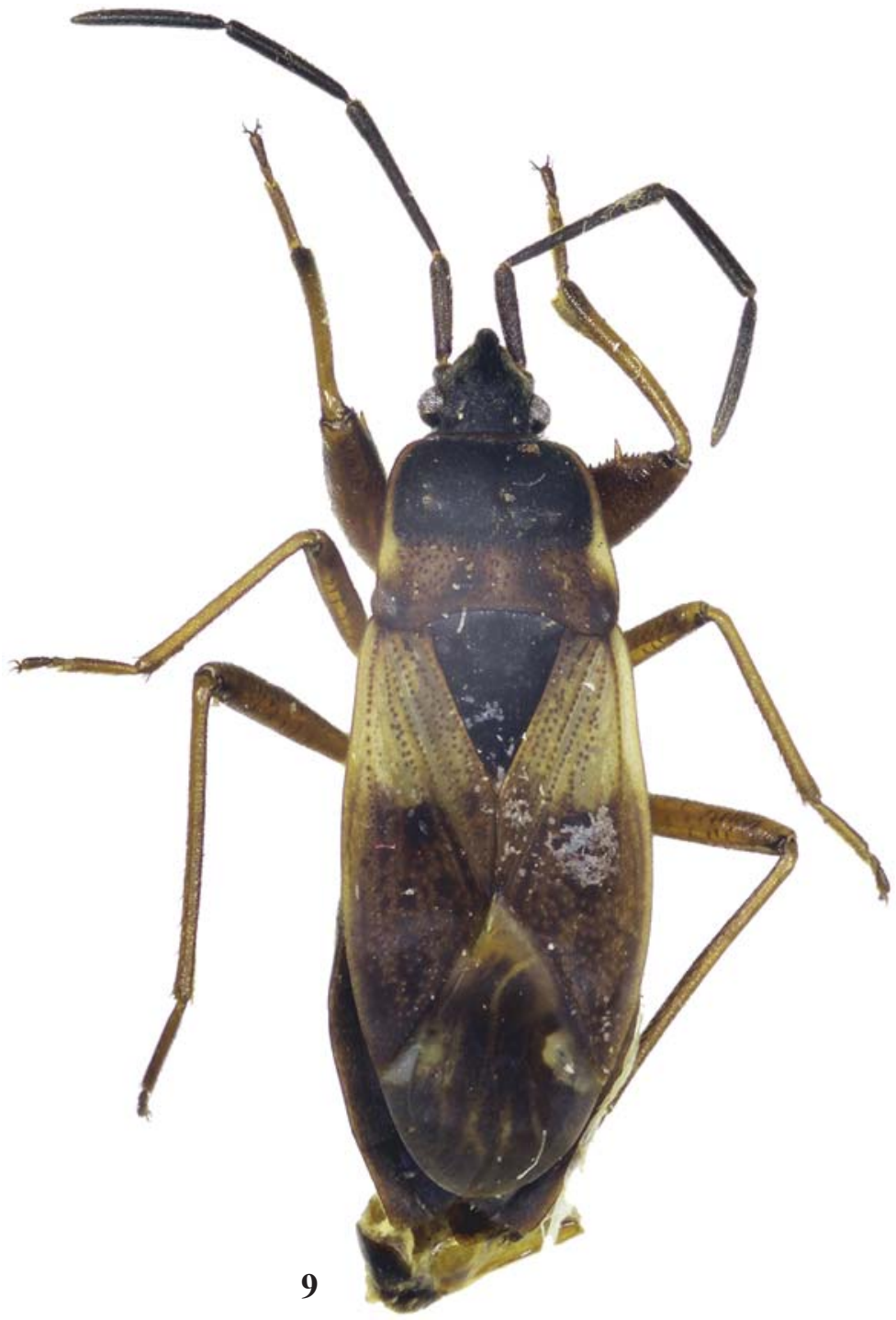

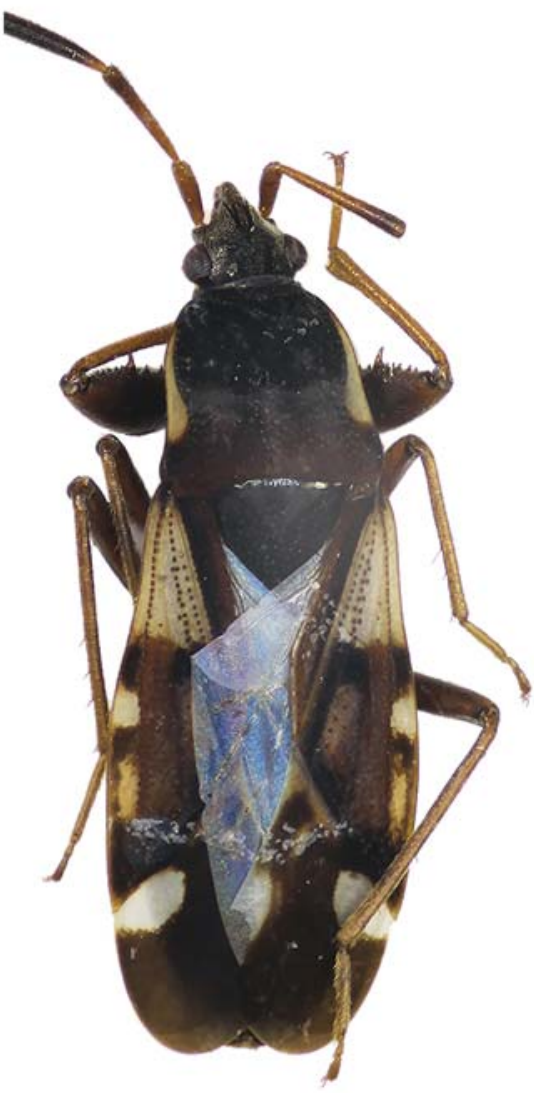

10

Figs 9-10. Eremocoris spp: $9-$ E. abietis, $ๆ$ (Eastern Siberia, South-Eastern Yakutia); 10 - E. angusticollis, + (Kunashir Is.). Рис. 9-10. Eremocoris spp: $9-$ E. abietis, + (Восточная Сибирь, Юго-Западная Якутия); 4 - E. angusticollis, 中 (о. Кунашир). 
archipelago, and $P$. dissimilis, distributed over the whole genus' range, in Japan as far northwards as Hokkaido Island, on the Korean Peninsula, and in the South-West and SouthEast of China [Tomokuni, 1998; Péricart, 2001].

The endemic genus Hidakacoris Tomokuni, 1998 was also described from the Japanese archipelago. Its only species, T. tsutsii (Hidaka, 1963) is distributed on Honshu, Shikoku, and Kyushu islands. The two genera are very close and reveal great external similarity but they clearly differ in the details of aedeagus morphology [Tomokuni, 1998].

Of the 11 species of the tribe Drymini occurring on the Kuril Islands, species of the genus Eremocoris Fieber, 1860, namely E. abietis (Linnaeus, 1758) (Fig. 9), E. insularis Kerzhner, 1977, and especially E. angusticollis Jakovlev, 1881 (Fig. 10) resemble $P$. dissimilis in the body length and the shape of the pronotum and particularly lamelliform lateral pronotal margin. However, the mentioned species of Eremocoris clearly differs from $P$. dissimilis in the bicolored pronotal disc, with a black anterior part and a pale to brown posterior part, and also in the hemelytral membrane having a large white spot near the posterior margin of the corium. By contrast, in species of the genus Paradieuches the pronotal disc is entirely black while the membrane is pale, translucent, with a large black or brown-black, diffusely outlined spot in the middle.

Acknowledgments. I am very grateful to Yu.N Sundukov and L.A. Sundukova (Kurilsky Nature Reserve) for the opportunity of examination of the bugs collected in the South Kurils in 2017 and F.V. Konstantinov (St. Petersburg) for valuable comments and editing the manuscript. This work was financially supported by the Siberian Branch of the Russian Academy of Sciences, project AAAAAA17-117020110058-4 (2017-2020), and the Russian Foundation for Basic Research, project 18-04-00464 (20182021).

\section{References}

Distant W.L. First Report on the Rhynchota collected in Japan by Mr. George Lewis // Transactions of the Royal Entomological Society of London. P.413-443.

Ishihara T. 1953. The insect fauna of Mt. Ishizuchi \& Omogo Valley, Iyo, Japan // Sikoku Entomological Society. Vol.3. Suppl. P.1-166.

Kerzhner I.M., Kanyukova E.V., Marusik Yu.M., Urbain B.K., Nakamura M., Lelej A.S. 2004. Heteroptera of the Kuril Islands: material collected by the International Expedition 1994-1999 and updated checklist // Zoosystematica Rossica. Vol.12. No.2. P.231-242.

Lethierry L., Severin G. 1894. Catalogue général des Hémiptères. T.2. Bruxelles: Hayers. 277 p.

Miyamoto S. 1957. List of ovariole numbers in Japanese Heteroptera // Sieboldia. Vol.2. P.69-82.

Oshanin B. 1912. Katalog der palaearktischen Hemipteren (Heteroptera, Homoptera-Auchenorryncha und Psylloidae). Berlin. S.i-xvi, 1-187.

Péricart J.A. 2001. Family Lygaeidae Schilling, 1829 — Seed-bugs // Catalogue of the Heteroptera of the Palaearctic Region. Vol.4. Amsterdam. P.35-220.

Scudder G.G.E. 1962. The World Ryparochrominae (Hemiptera: Lygaeidae). I. New synonymy and generic changes // Canadian Entomologist. Vol.94. P.764-773.

Slater J.A. 1964. A catalogue of the Lygaeidae of the World. Vols 12. Baltimore, Maryland, USA: Waverly Press. 1668 pp.

Slater J.A., O’Donnel J.E. 1995. A catalogue of the Lygaeidae of the World (1960-1964). New York. 410 pp.

Tomokuni M. 1998. A revision of the systematic position of Dieuches tsutsuii Hidaka and Paradieuches Distant (Heteroptera, Lygaeidae, Rhyparochrominae) // Memoirs of the National Science Museum Tokyo. Vol.31. P.231-236.

Vinokurov N.N. 2017. [First record of bug Plinachtus bicoloripes Scott, 1874 (Heteroptera, Coreidae) for the fauna of Russia from the South Kurils] // Evraziatskiy Entomologicheskiy Zhurnal. Vol.16. No.1. P.8-9 [in Russian, with English summary].

Vinokurov N.N., Kanyukova E.V. 2016. [New records of bugs (Heteroptera) from Kunashir and Shikotan // Evraziatskiy Entomologicheskiy Zhurnal. 2016. Vol.15. No.1. P.25-28 [in Russian, with English summary]. 